\title{
Demotic Ostraca and Their Use in Egyptian Temple Context from the Greco-Roman Period: Soknopaiou Nesos and Hut-Repit
}

The focus of this article lies on the ostraca from the temple complexes of Soknopaiou Nesos in the Fayum and Hut-Repit in Middle Egypt written in Demotic, a cursive writing system used from the seventh century BCE to the fifth century CE. The two roughly contemporary sets of ostraca provide the opportunity to compare the use of Demotic ostraca for different text forms and text types and the role of potsherds versus other writing materials in the administrative, economic, and cultic life of Egyptian provincial temples in the late Ptolemaic to early Roman period.

\section{The Sites and Their Text Material}

\subsection{Soknopaiou Nesos}

The site lies on the northern edge of the Fayum Lake. The name 'Soknopaiou Nesos' is the Greek rendering of the Egyptian name $T 3-m$ ' $y(. t)$-Sbk-nb-Pay, 'Island of (the

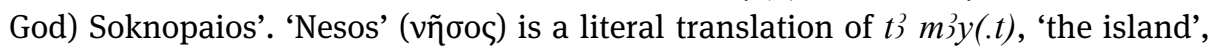
from which the designation 'Dime' or 'Dimai' still in use today is derived. The god Soknopaios is a local form of the crocodile deity Sobek, who gave the site its name. ${ }^{1}$ The village is mentioned for the first time around 240 BCE, but Dime experienced its heyday, as far as we can tell from the documents thus far found, in the first and second centuries of the Common Era. Around 230 CE, evidence of a continuous settlement at the site breaks off; it was abandoned and no longer inhabited on a permanent basis. ${ }^{2}$ The large temple precinct of the god Soknopaios, with its almost 400 meters long dromos, remains the most distinct characteristic of the site (Fig. 1). It belonged to the $\lambda o ́ y \iota \alpha$ ícó, sanctuaries of the first rank, ${ }^{3}$ and was the religious, cultic, social, and economic center of Dime and the region.

\footnotetext{
1 Clarysse 2005, 20-21.

2 Clarysse 2005, 23-26. For possible frequentation of the site in Late Antiquity, see Davoli 2015, $142-145$. 3 Cf. BGU XIII 2215, introduction. The oldest evidence for this can be found in BGU III 706 1. 5, 119 CE, Soknopaiou Nesos.
}

\footnotetext{
Abbreviations used in this article: $B D=$ Book of the Dead (Totenbuch); DDD I = Lippert/Schentuleit 2006; DDD III = Lippert/Schentuleit 2010; PT = Pyramid Texts (Pyramidentexte). 


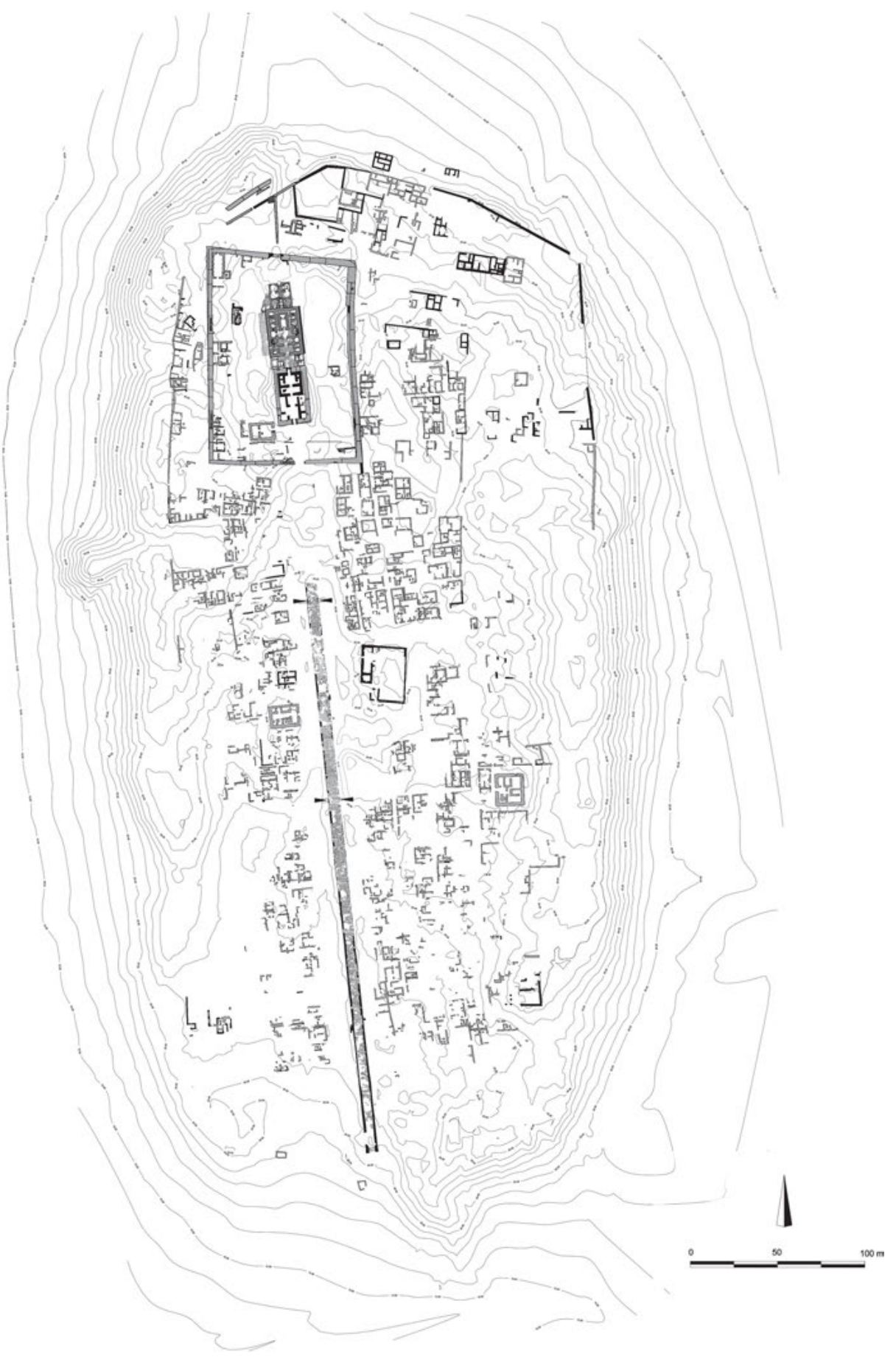

Fig. 1: General plan of Dime/Soknopaiou Nesos (2017). 
Texts on papyrus and ostraca were found in large quantities by every expedition since the 1890s, and most of them ended up spread over European and North American collections. Archaeological research at the site began with sporadic visits from scholars such as Richard Lepsius in the years 1842 to $1846 .{ }^{4}$ The first excavations, in the years from 1890 to 1910, were scarcely documented. The first scientific excavations in the urban area were conducted and published in the 1930s by the University of Michigan. ${ }^{5}$ Since 2001, an Italian expedition, initially a joint undertaking of the universities of Bologna and Lecce, and since 2004 under the leadership of the Center for Papyrological Studies of the University of Lecce, has been working on the site. ${ }^{6}$ Besides a small number of texts written in hieratic and hieroglyphs, the evidence is composed essentially of Demotic and Greek and encompasses a broad spectrum of literary, religious, and documentary texts, the bulk of them consisting of all manners of administrative documents. ${ }^{7}$ Only a small number of texts stem from the Ptolemaic period, the vast majority can be dated to the Roman period. ${ }^{8}$

With respect to the Demotic material, only 247 of the ostraca, which are the focus of this article, have been published so far (see Tab. 1). ${ }^{9}$ Some of them were found within the temple precinct, while others were recovered beyond the town wall to the west of the settlement area in ancient rubble heaps as well as in the dumps formed by the excavations at the beginning of the twentieth century. Stadler speculates that a part of the material might have been deposited in a building between the temenos and the town wall. ${ }^{10}$ The findspot of the material, as will be argued later on, is crucial for its interpretation.

On the basis of the paleography the material has to be dated to the Roman period. ${ }^{11}$ The findspots and content of the ostraca indicate that they are to be associated with the administrative and economic activities at the temple.

\footnotetext{
4 Capasso/Davoli 2012, 11-18.
}

5 Boak 1935.

6 The reports of the mission from 2003 onwards are available in Italian and English via the website of the Soknopaiou Nesos Project (SNP): http://www.museopapirologico.eu/sok_rep.htm (last accessed: 14.10.2018).

7 The best and most recent overview can be found via Trismegistos Texts: www.trismegistos.org/tm/ index.php (last accessed: 14.10.2018). A series of religious and literary manuscripts in a wider sense that have traditionally been attributed to Soknopaiou Nesos (the so-called Serpot group) are unlikely to have been written by scribes educated there, see Stadler 2015, 189-232.

8 Clarysse 2005, 25-27.

9 DDD I; Pernigotti 2008. In the meantime, Caputo was able to join several of the 227 published fragments of ostraca, cf. Caputo/Cowey 2018, 62-75.

10 Stadler 2012, 266-267.

11 Just a few ostraca show a year date, e. g. DDD I 189 = TM 99501 col. 2 1. 1: regnal year 41 which can refer only to Augustus (=11/12 CE). 
Tab. 1: Texts from Soknopaiou Nesos.

\begin{tabular}{lcc}
\hline & $\begin{array}{l}\text { Status 2018 according to the } \\
\text { TM }^{12} \text { and HGV }\end{array}$ & $\begin{array}{l}\text { Additional unpublished } \\
\text { material }\end{array}$ \\
\hline Demotic papyri & $332(\mathrm{TM})$ & $+\sim 1800^{14}$ \\
\hline Hieratic papyri & $12(\mathrm{TM})$ & - \\
\hline Hieroglyphic papyri & $3(\mathrm{TM})$ & $+2^{15}$ \\
\hline Coptic papyri & - & $1^{16}$ \\
\hline Greek papyri & $1107(\mathrm{HGV})$ & $+>89^{17}$ \\
\hline Demotic ostraca & $247(\mathrm{TM})$ & $+\sim 600^{18}$ \\
\hline Greek ostraca & $3(\mathrm{HGV})$ & $+>20^{19}$ \\
\hline Coptic ostraca & - & $3^{20}$ \\
\hline Bilingual papyri (Demotic/Greek) & $105(\mathrm{HGV}+\mathrm{TM})$ & $\sim 2^{21}$ \\
\hline Bilingual papyri (Demotic/hieratic) & $5(\mathrm{TM})^{22}$ & - \\
\hline Bilingual ostraca (Demotic/Greek) & - & $1^{23}$ \\
\hline Demotic dipinti & - & $6^{24}$ \\
\hline
\end{tabular}

12 Trismegistos Texts Database, https://www.trismegistos.org/tm/ (last accessed: 17.1.2020).

13 Heidelberger Gesamtverzeichnis der griechischen Papyrusurkunden Ägyptens, http://aquila.zaw. uni-heidelberg.de/texte/HGV-Texte.html (last accessed: 17.1.2020).

14 The number is based on the research of the projects "Soknopaiu Nesos nach den demotischen Quellen römischer Zeit" (Würzburg, from 2000 to 2005) and “DimeData: Online Platform for Editing Roman Period Accounts from the Soknopaios Temple in Dimê (Fayum)" (Bordeaux and Würzburg, ongoing from 2018); on a report of Stadler 2012, 251-254 (mentioning 73 fragments); and on the SNP reports (more than 53 texts, partly overlapping with the material mentioned by Stadler).

15 SNP Reports 2004 and 2012.

16 SNP Report 2006.

17 SNP Reports 2004-2010, 2012, 2014, 2016, and 2017. Cf. Jördens 2005, 42: “Inzwischen wird man zuversichtlich von rund 1100 edierten griechischen Papyri sprechen können, denen eine unbekannte Zahl noch unedierter Texte gegenübersteht”.

18 The number is based on a report of Stadler 2012, 255-263 (listing 199 ostraca) + addendum, p. 268 (mentioning another 157 ostraca) as well as on the SNP Reports (listing about 600 ostraca, partly identical to the material mentioned by Stadler).

19 SNP Reports 2003, 2005, 2007, 2009, 2010, 2012, 2014 and 2017. Cf. Jördens 2005, 42 with fn. 7.

20 SNP Report 2008 and 2009.

21 SNP Report 2004 and 2005. Stadler 2012, 251 mentions fragments with Greek (nos. 13 and 19).

22 TM 128430 is strictly speaking Demotic in hieratic script.

23 SNP Report 2010.

24 Stadler 2012, 263-264. 
Tab. 1: continued.

\begin{tabular}{lcc}
\hline & $\begin{array}{l}\text { Status 2018 according to the } \\
\text { TM and HGV databases }\end{array}$ & $\begin{array}{l}\text { Additional unpublished } \\
\text { material }\end{array}$ \\
\hline $\begin{array}{l}\text { Demotic inscriptions } \\
\text { - stelae }\end{array}$ & $1(\mathrm{TM})$ & \\
- statue & $1(\mathrm{TM})$ & $3^{25}$ \\
- naoi & - & $2^{26}$ \\
\hline Hieroglyphic inscriptions & - & $1^{27}$ \\
\hline Hieratic inscriptions & - & $>6^{28}$ \\
\hline Greek inscriptions & - &
\end{tabular}

\subsection{Hut-Repit}

The ancient town of Hw.t-Rpy.t, the 'House of the goddess Repit', is situated near modern Sohag in Middle Egypt. The site was excavated by Flinders Petrie in $1907 .{ }^{29}$ In the 1980s, the Egyptian Antiquities Service re-opened excavations there; since 2003, a German-Egyptian mission under the direction of Christian Leitz, of the University of Tübingen, has been working there for several months a year. ${ }^{30}$

The site (Fig.2) includes a temple built under Ptolemy XII, which is where the current mission is concentrated. There was another, earlier temple, at right angle to it, which is buried under rubble and nowadays practically invisible. Later, a monastery was built around the temple of Ptolemy XII. The living quarters of the town have not yet been explored.

In the southwest, the site is bordered by the steep cliff of the gebel in which ancient quarries, numerous tombs, and a small speos (rock-cut temple) had been dug. When in October 2017 S. Lippert presented the Demotic material from Hut-Repit, it comprised almost 400 Demotic ostraca (out of about 550) and roughly 150 dipinti and graffiti on the walls of the temple of Ptolemy XII, the façade and walls of the

\footnotetext{
25 Stadler 2012, 264.

26 SNP Report 2006.

27 SNP Report 2012.

28 SNP Report 2007, 2008, 2011, 2012, and 2017.

29 Results published in Petrie 1908.

30 Abul-Yazid et al. 2019. See also the site of the Tübinger Tempelprojekt Athribis, https://www.unituebingen.de/fakultaeten/philosophische-fakultaet/fachbereiche/altertums-und-kunstwissenschaften/ ianes/forschung/aegyptologie/projekte/athribis-projekt-dfg.html (last accessed: 17.1.2020).
} 


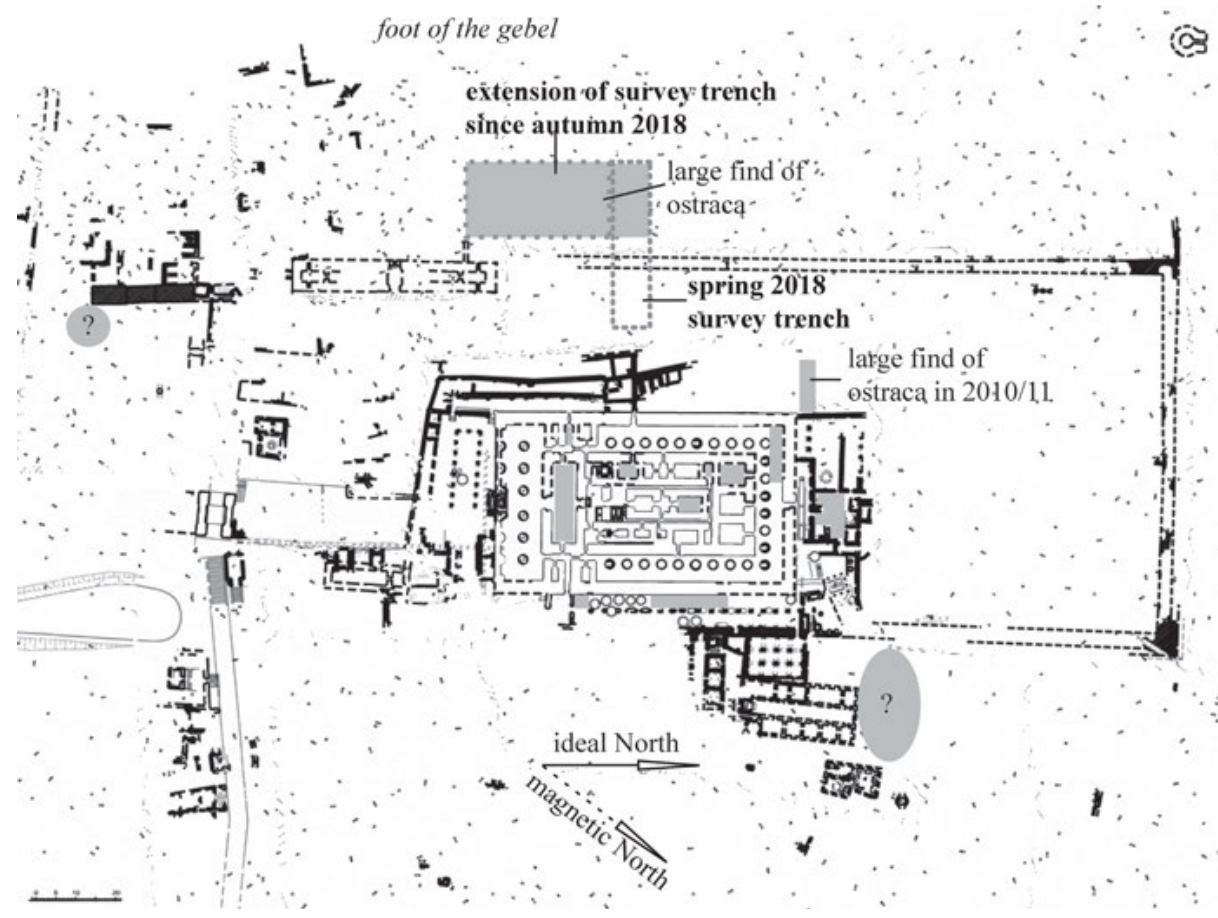

Fig. 2: Map of the site showing the findspots of ostraca in grey.

aforementioned speos, ${ }^{31}$ as well as on an unfinished reused composite capital. It is interesting to note that the recent excavations did not unearth any Demotic papyri. A large number of ostraca was found within a relatively short period of time at the end of the 2010 campaign and the beginning of the 2011 campaign, in an area which at the time was thought to have been an ancient rubbish dump, at the north-western corner of the temple. Another group came from what is probably the rubble heap of Petrie's 1907 excavation. Cleaning the terrace of the speos also brought to light some ostraca, and some more were found inside the temple of Ptolemy XII, but since this area was heavily impacted by later reuse, the ostraca found there were certainly not in situ. There were also random surface finds all over the site.

Since then, the situation has changed dramatically. In February and March 2018, further 1,450 ostraca were uncovered in a narrow exploratory trench outside one of the gates in the western enclosing wall of the temple (Fig.2). It turned out that this area had been used by sebbakhin to dump the larger bits and pieces left over from sifting

31 The Demotic inscriptions of this speos are mentioned in a report by El-Farag/Kaplony-Heckel/ Kuhlmann 1985, 1-4. They are edited by S. Lippert in her Habilitationsschrift (submitted 2018, to be published in the series Athribis at the IFAO). For a preliminary report, see Lippert 2014, 145-153, but note that more inscriptions have since been discovered. 
decayed mud bricks widely used as fertilizer (sebbakh) in the nineteenth and early twentieth centuries. This circumstance makes it likely that the findspot of the mass deposit of ostraca found in 2010 and 2011 is also part of the same sebbakhin dump, which probably runs along the whole western side of the temple of Ptolemy XII. The exploration of this dump continues, and by the end of March 2020, over 10,000 new ostraca had been brought to light. This material will be examined and edited by an international research group coordinated by S. Lippert.

The new finds also shift the proportions between the languages, although the most recent finds have not yet been evaluated statistically at the time this article was finished and therefore could not be included.

Tab. 2: Texts from Hut-Repit.

\begin{tabular}{lrr}
\hline & Found in 2005-2016 & Found in spring 2018 \\
\hline Total Ostraca Finds & 543 & 1450 \\
\hline Demotic & 378 & ca. 1050 \\
\hline hieratic & 6 & 12 \\
\hline hieroglyphic & 0 & 3 \\
\hline Greek & 59 & 139 \\
\hline Coptic & 24 & 9 \\
\hline Greek or Coptic? & 48 & 0 \\
\hline Arabic & 9 & 0 \\
\hline drawings & 9 & 66 \\
\hline unclear & 10 & ca. 171 \\
\hline
\end{tabular}

The excavation of the sebbakhin has removed the original stratigraphy and turned it upside down, bringing the oldest layers above the most recent. The result of this seems to be clearly visible in the table showing the newly found material, which seems to come mainly from older archaeological layers, as there are no Arabic ostraca and very few Coptic. On the other hand, ostraca with drawings, which range from geometric designs such as squares, rectangles, or stars to depictions of animals, persons, and divinities, are much more frequent.

The majority of the Demotic ostraca, perhaps as much as two thirds, clearly belonged to the administration and economy of the temple-there are numerous accounts and lists, as well as some receipts. About 40 currently known Demotic wine jar labels (dipinti) also fall into the category of texts from the temple administration and economy. 
Another group, already present in the 2005-2016 finds, but noticeably increased through the new finds, is formed by school texts. These include beginners' writing exercises, grammatical and mathematical texts (teacher's models or pupils' copies), and model letters. Incidentally, this increase shows that the temple school, dug up by the sebbakhin, was probably situated somewhere in the western or northern part of the temple precinct. The small number of magical, religious and astronomical texts was of course also the result of priestly activities.

\section{Text Forms and Text Types}

We will start with the text forms that are present in both sites. "Text Form" refers to the larger categories that can be defined through form and function, while "Text Type" refers to sub-groups within these categories. ${ }^{32}$

\subsection{Accounts}

This group of documents is characterized by a list form with the text in two columns: The one on the right registers individuals and/or institutions and the left one records amounts of money or quantities.

At Soknopaiou Nesos, 37 out of 800 ostraca have already been identified as belonging to this group, usually mentioning either individuals (account Type $\mathrm{A}^{33}$ ) or institutions (account Type $\mathrm{B}^{34}$ ) which are each assigned an amount of money ${ }^{35}$ or a quantity of wheat ${ }^{36}$ or bread ${ }^{37}$. Professional titles of the individuals are very rare (e. $\mathrm{g}$. DDD I 189 = TM 99501), occasionally we find headings (e. g. DDD I 189 = TM 99501) and dates (e. g. DDD I 192 = TM 99504).

32 An intentional space in the Demotic text is indicated by $\square$; a space line by $\square \square \square$.

33 E. g. DDD I 182 = TM 99494, DDD I 183 = TM 99495, DDD I 187-190 = TM 99499-99502.

34 E. g. DDD I 181 = TM 99493, DDD I 184 = TM 99496, DDD I 192-193 = TM 99503-99504.

35 E. g. DDD I $176-177=$ TM $99488-99489$.

36 E. g. DDD I 178-185 = TM 99490-99497, DDD I 186+182 = TM 99494, DDD I 187-192 = TM 9949999504.

37 E. g. DDD I 193-194 = TM 99505-99506. The correct reading of the group designating the bread loaves is uncertain. Zauzich 1984, 89, had proposed $g$; 9 3), in DDD I, pp. 5-6, we opted for gsgs(?), while Stadler (2012, 258 n.2) recently suggested snsn. Perhaps sn.wy as a phonetic writing of snw "offering bread" (Wb. IV, 155) is meant. 
DDD I 182 (= TM 99494)

Account Type A (wheat) ${ }^{38}$

$1 \quad P a-H^{c} p y(s 3)$ Nht.t $t-n b=f^{1 / 10}$

$2 \quad S t 3 . t=w-t 3-w t y \quad p 3 y=f \check{s} r r^{1 / 10}$

$3 \quad H t b 3$ p $3 y=f \check{s} r \quad \square 1 / 10$

$4 \quad H r(s 3) H r-p y t\left(s^{3}\right) W n-n f r^{\text {c.w.s. }} 1 / 10$

$5 \quad H r=w\left(s^{3}\right) H r-p y t \square^{r_{1} / 10^{7}}$

$6 r \mathrm{Hr}\left(\mathrm{s}^{3}\right) \mathrm{Hr}=\mathrm{w}^{\top}[\ldots]$
Paopis (son) of Nestnephis: $1 / 10$ (artabe)

Stothoetis his son: $1 / 10$ (artabe)

Satabus his son $\square 1 / 10$ (artabe)

Horos, (son) of Harpagathes, (son) of

Onnophris ${ }^{\text {L.P.H. }}: 1 / 10$ (artabe)

Herieus (son) of Harpagathes $\square 1 / 10$ (artabe)

Horos (son) of Herieus [...]

DDD I 184 (= TM 99496)

Account Type B (wheat) ${ }^{39}$

col. 2

$\mathrm{x}+4$ sw 21 t3 ' $h n y y(. t)^{\prime} c^{3}(. t) r t b 4$ sw $10[+x \ldots]$

$\mathrm{x}+5$ sw 22 t3 $\underline{h n y}(. t) \ldots s w 12 w h m 1 \square s w$

$1^{r} 7^{\prime}(?)$

$\mathrm{x}+6$ sw 26 t3 hny(.t) sw 15(?) .. sw 16 sw 17

$\mathrm{x}+7{ }^{2} r b^{r} 2^{7}$ jn $\mathrm{Hr} n=y^{r} \ldots . .{ }^{\top}$

$\mathrm{x}+8$ sw 18 t3 $\operatorname{hny}(. t){ }^{\mathrm{c}} 3(. t)$ sw 18

$\mathrm{x}+9$ sw 19 sw 20 sw $21 \mathrm{rrtb} 4$ day 21: the big revenue collection: 4 artabai; day $10[+\mathrm{x} \ldots]$

day 22: the revenue collection ...; day 12 plus:

$1 \square$ day $17(?)$

day 26: the revenue collection; day 15(?) .. day 16,

day 17

2 artabai. Horos brought to me .......

day 18: the big revenue collection; day 18 , day 19, day 20, day 21: total 4 artabai

...

It is not always clear whether revenues or expenses of the temple treasury are meant, but headings like "the list of the individuals who took wheat" (DDD I 180 = TM 99492), "the list of priests who take wheat in regnal year 41" (DDD I 189 = TM 99501) show that we are at least sometimes dealing with expenses of the temple granary. In contrast to the allocation lists that will be encountered later, these accounts mention specified quantities of money or products and these quantities are not equal in value. Several of these lists show check marks of different kinds: dots, crosses and slashes. ${ }^{40}$

At Hut-Repit accounts are by far the largest group among the Demotic ostraca. As is usually the case with this type of texts, the scribe limited himself to the minimum of information. If, as often, there is no heading such as "what NN has brought" or "for

38 In Soknopaiou Nesos it is customary not to write the unit $r t b$ "artabe" when the quantity is below one artabe, cf. DDD I, p. 6. L.P.H. is the abbreviation of "he may live, prosper and be healthy" ( ${ }^{c} n h \underline{h} w$ ) $s n b$ ). In Soknopaiou Nesos several personal names show this formula which is otherwise common for $\mathrm{Pr}_{-} \mathrm{C}$ ' "pharaoh".

39 Only a part of the text is presented here. In line $\mathrm{x}+5$, read $s w 22$ t3 $\underline{h} n y(. t)$... instead of $s w 22 \ldots \ldots \ldots . .$. (ed.pr.).

40 E. g. DDD I 189 = TM 99501 col. 2; 192-193. 
the money expense," one wonders whether the listed commodities were paid out or received by the temple. The occasional use of ambiguous prepositions that can mean either "to the hand of someone," that is "for someone," or "from the hand of someone," or even "in the hand of someone," that is, in his/her possession, does not help either. Also, many accounts only give numbers in the second column and thus leave us guessing whether a commodity or money is meant. From those that clearly mention a commodity, we can gather that the temple administration was involved in the stocking and distribution of cereals-usually wheat, but sometimes also barley-, bread, wine and fruit-mainly dates, but also dum palm and argun palm fruits, and possibly carob. Unlike at Soknopaiou Nesos, individuals as well as institutions can be mentioned in one and the same account (account Type $\mathrm{C}$ ), while in others, commodities or other purposes of payment are listed in the first column (occasionally preceded by "price of" or "for"), and amounts of money in the second (account Type D).

\subsection{Lists}

This text form lists individuals, entities or items without an amount of money or a quantity of a product. However, sometimes one cannot be sure if the second column with amounts or quantities is just broken off, so that some of the texts may actually belong to the category "accounts".

Three main groups are to be recognized: texts with personal names (list Types A-D), lists of real estate (list Type E), and inventory lists (list Type F). The documents of the first category can be divided into those which show personal names without details about the individuals who are recorded (list Type A), those with names and specification of the phyle (list Type $\mathrm{B}$ ), and those with names and professional titles (list Types C and D). Type A is present at both sites, Type B only in Soknopaiou Nesos, Types C, D, E, and F only in Hut-Repit.

About 80 ostraca from Soknopaiou Nesos belong to lists of Types $\mathrm{A}^{41}$ and $\mathrm{B}^{42}$ : (i) Lists with headings like "list of the individuals who took wheat" 43 or "taking wheat" ${ }^{44}$ or those identifying the individuals as participants of specific festivals ${ }^{45}$ are most likely to be seen as allocation lists (for one possible exception see below). Priests

41 E. g. DDD I 36 = TM 99356, DDD I 37+83 = TM 99357, DDD I 38 = TM 99358, DDD I 39+70 = TM 99359, DDD I 40-46 = TM 99360-99366, DDD I 55-59 = TM 99375-99379, DDD I 62+66 = TM 99386, DDD I 63-65 = TM 99383-99385, DDD I 68 = TM 99388, DDD I 69+73 = TM 99389, DDD I 71 = TM 99391, DDD I 74-82 = TM 99394-99402, DDD I 84-85 = TM 99404-99405.

42 E. g. DDD I $24+27+54+81$ = TM 99344, DDD I 25-26 = TM 99345-99346, DDD I 28-34 = TM 9934899354.

43 E. g. DDD I 34 = TM 99354 1. 8; DDD I 37+83 = TM 99357 1. 1; DDD I 180 = TM 99492 1. 1.

44 E. g. DDD I 56 = TM 99376 l. $\mathrm{x}+12$.

45 E. g. DDD I 31 = TM 99351 col. II 1. $x+2$. 
received rations as part of their pay from the temple, and the distribution of these payments in kind might be documented by these lists as part of the temple book keeping. If all individuals were to receive the same amount of money or the same quantity of a product, that could explain absence of their records. This will be discussed later on. (ii) Lists without headings might have served to check the presence of individuals at a certain event within the temple milieu, in which case they could be attendance lists. It is also conceivable that these attendance lists were the basis for the already mentioned allocation lists. Occasionally, we also find day dates and check marks in front of the names; sometimes the number of individuals is summed up. Some of the name lists with specification of the phyle could be the Egyptian counterpart to the lists of phyle-members written in Greek on papyrus, ${ }^{46}$ but unlike the Demotic documents, the Greek ones usually record the father's, grand-father's and mother's names as well as the age of the priest, because these documents were used for control purposes by the Roman fiscal administration.

\section{DDD I 37 (= TM 99357) ${ }^{47}$ \\ List Type A ii}

$\left.1 \quad[p]^{3}\right]^{r 2 T}[p]^{r} r m t(?)^{\top}[n b \text { nty }]^{r} t 3 y^{\top} s w{ }^{3}$

$2 \quad H r=w(s 3)^{r}{ }^{r} \ldots{ }^{\top}[\ldots]\left(s^{3}\right) N h t-n b={ }^{r} f^{\prime}$

$3 \quad$ Pa-n3-nfr-i-imy (s\}) [......] (p3) hm

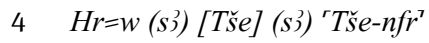

$5 \quad$ Nht.t-nb=r' $f^{\prime}\left(s^{3}\right) T s ̌ e(s 3) T s e-n f r$

$6 \quad{ }^{\prime} T \check{s} e-n f r p 3 y=f \check{s} r^{\top}$

$7 \quad{ }^{r} S t 3 . t=w-t 3-w t y^{\top}$ (s3) Pa-nj-nfr-i-imy (si)

Hr-pyt (p3) hmm
List of everyone(?) [who] takes wheat Herieus (son) of ...[...] (son) of Nestnephis Panephremmis (son) of [......] the younger Herieus (son) of [Teses] (son) of Tesenuphis Nestnephis (son) of Teses (son) of Tesenuphis Tesenuphis, his son Stotoethis (son) of Panephremmis (son) of Harpagathes the younger

DDD I 25 (= TM 99345)

\section{List Type B ii}

1 p3s3 5(.nw) Pa-n3-nfr-imy (s3) $\mathrm{Hr}\left(\mathrm{s}^{3}\right)$

$2 H r=w(s 3) Q r-\underline{d} 3 \underline{d} 3(s 3) W n-n f r$ Wty (p3) hm

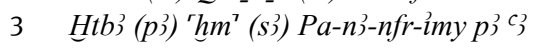

$4 \quad$ St $3 . t-w t y\left(s^{3}\right) \mathrm{Gmr}$

$5 \quad H r$-pyt (s3) $H t b 3\left(s^{3}\right) H r^{r}-p y t^{7}$

6 Sti.t. wty (p3) hm (si) $\mathrm{Hr}^{\mathrm{r}} \mathrm{pa}^{\mathrm{T}}[\ldots]$

$7{ }^{r} H t b 3^{7}[\ldots]$
The fifth phyle: Panephremmis (son) of Horos (son) of Uetis (the) younger Herieus (son) of Kalatytes (son) of Onnophris Satabus (the) younger (son) of Panephremmis the elder Stoethis (son) of $\mathrm{Gmr}$ Harpagathes (son) of Satabus (son) of Harpagathes Stoethis (the) younger (son) of $H r^{r} p a^{7}[. .$. Satabus [...]

46 Cf. P.Louvre I 5 and 6 (2nd century CE, Soknopaiou Nesos), labelled as "Priesterliste"; see further references there.

47 In contrast to the ed.pr., I (M. S.) do not any longer interpret the space between 1.1 and 2 as a blank line. 
So far, there is only one example in the material that shows the verb $d l$ "give" instead of $t 3 y$ "take" in the heading. If it is not a mistake, the document could be a delivery list:

DDD I 35 (= TM 99355)

List Type B i “delivery list?”

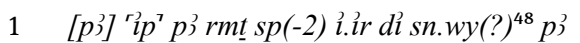

The list of the individuals who gave bread. The s3 $5(. n w)$

$2 \quad S t 3 . t=w-t 3-w t y(s 3) G m l$

Stotoethis, (son) of $\mathrm{Gml}$

fifth phyle:

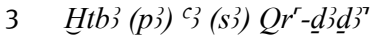

$4 \quad P a-n 3-n f r-i m y(p 3) h m\left(s^{3}\right) Q^{r} r-d i d 3^{3}$

$5 \quad c_{n h}=f(s 3) H r-p a-' I s . t$

$6 \quad$ Pa-n3-nfr-imy (s3) $\mathrm{Hr}^{-}{ }^{\mathrm{r}} \ldots{ }^{\mathrm{T}}$

$7 \quad H r-p y t(s 3) S t 3 . t=w-t 3-w t y$

$8 \quad H_{t b} 3\left(s^{3}\right) H r=w\left(s^{3}\right)^{r} Q l-\underline{d} j \underline{j} j^{3}(?)$

$9 \quad[$ sw] $15 \square 7$

Satabus (the) elder, (son) of Kalatytes

Panephremmis (the) younger, (son) of Kalatytes

Anchopis (son) of Harpaese

Panephremmis (son) of $H^{-r}{ }^{r} \ldots{ }^{\top}$

Harpagathes (son) of Stotoethis

Satabus (son) of Herieus (son) of Kalatytes(?)

$\square \square \square$

[day] $15 \square 7$

Lists of individuals without amounts of money or quantities of products from Hut-Repit generally lack clear headings, although some contain day dates as subtitles. The purpose of these lists of persons remains usually obscure, but as in Soknopaiou Nesos, they might have been used to check attendance and/or document eligibility for allocations.

A remarkable feature of the accounts and lists from Hut-Repit is a comparatively large number of female names among the persons mentioned. Not all persons are identified by professional titles (names without titles: List Type A), but we find for example builders and mud carriers, boatmen, weavers, a wet-nurse, and even a eunuch (List Type C: names with professional titles; and Type D: mixed type). On the other hand, there appear practically no priestly titles, perhaps because this was the default anyway.

Only attested in Hut-Repit are lists of real estate, designated as 'houses' ( ${ }^{c}$.wy) or 'places' $(m)^{3}$ or s.t), and identified by their owner (List Type E); one also contains measurements in cubits. In case of the 'places' (s.t), this could also mean tombs or pastophoria, that is, the small huts inside the temenos in which the priests lived during their month of service. ${ }^{49}$ It remains unclear what function these lists of real estate served within the temple administration.

Object inventories from Hut-Repit show characteristic features of accounts, namely two columns-sometimes the name of the object, sometimes its material and/or its function is given in the first column and a quantity in the second column

48 Regarding the reading, cf. fn. 37.

49 Cf. the sale of a pastophorion DDD III 32 = TM 109362. 
(List Type F)-but it is not very likely that they are accounts. Actually, the purpose of these inventory lists can be gathered from Greek texts: The Roman administration obliged temples to hand in yearly statements about their possessions, including cult objects, ${ }^{50}$ and it is conceivable that these notes served as basis for these temple reports.

Lists which sum up the members of each phyle are not documented anywhere outside Soknopaiou Nesos (Phyle Counts: Lists Types G and H). Currently, 24 documents of this kind are known. The most frequently occurring form is the one showing a list mentioning each phyle followed by a number either directly or at a distance in a second column (Lists Type G). These numbers represent most likely the number of phyle members in the temple of Soknopaios on a specific day, because occasionally we find a day date at the beginning of the text and the word $r m t$ "person" before the numbers.

DDD I 4 (= TM 99325)

\section{List Type G (Phyle Count)}

$1 \quad$ si tp $\square 21$

2 si $2 . n w \square \square^{r} .{ }^{\prime}$

3 s3 $3 . n w \square 31$

4 s) $4 . n w \square 14$

$5 \quad s 35(. n w) \square 18$

\author{
First phyle $\square 21$ \\ 2nd phyle $\square$.. \\ 3rd phyle $\square 31$ \\ 4th phyle $\square 14$ \\ 5(th) phyle $\square 18$
}

Less frequent is the type that lists phyle 1 to 5 , each followed by one proper name plus filiation, and the number of the members of the phyle; occasionally, these lists are preceded by a day date. The mentioned individual is probably the phylarch (List Type H).

DDD I 3 (= TM 99324)

\section{List Type H (Phyle Count)}

1 s3 tp Pa-n3-nfr-imy (s3) $\mathrm{Hr}\left(s^{3}\right) \mathrm{H} t \mathrm{H}^{3}$

$2 \quad r m t 31$

3 s) $2 . n w S t 3 .\{t\} t=w-t\}-w t y(s\}) H r-p a-' I s . t$ $r m \underline{t} 1^{r} 4^{7}$

4 si 3.nw Hr (si) P3-mie rmt 29

5 si $4 . n w$ Tše $(s i) ~ N h t . t-n b=f r m t 26$

6 s3 $5(. n w) S t 3 .\{t\} t=w-t\}-w t y(s\}) Q l-d i d\}$

$7 \square r m \underline{t} 28$
First phyle: Panephremmis (son) of Horos (son) of

Satabus:

31 persons

2nd phyle: Stotoethis (son) of Harpaesis: 14

persons

3rd phyle: Horos (son) of Pmois: 29 persons

4th phyle: Teses (son) of Nestnephis: 26 persons

5(th) phyle: Stotoethis (son) of Kalatytes

$\square 28$ persons

50 Cf. P.Zauzich 12 = TM 46246: Dousa/Gaudard/Johnson 2004, 184 n. 86. See also ST06/344/1366, an unpublished Greek list of priests and goods of the temple of Soknopaios, dated to the end of 2nd-be-

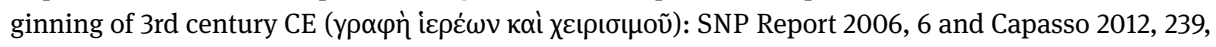
no. 79 . 
These phyle counts are most likely attendance lists. It is conceivable that they could have been relevant in the context of allocations.

\subsection{One-/Two-Name Ostraca}

The vast majority of the ostraca from Soknopaiou Nesos, about 400, show one or two proper names with filiation, i. e. the father's and occasionally the grandfather's names (Type A). Titles appear rarely and all are priestly (Type B). We can exclude that these sherds belong to jar labels because their size and format are quite uniform. ${ }^{51}$

DDD I 139 (= TM 99453)

One-Name Ostracon Type A

$1 \quad$ Sti.t. t-wty (si) ' $I w=f-c^{-} n h$

2 (s3) $P 3 y-B s$

Stoetis, (son) of Apynchis, (son) of Pibes

DDD I 108 (= TM 99422)

One-Name Ostracon Type B

$1 \quad H r=w(s 3) H r(s 3) H t b 3$

Herieus (son) of Horos, (son) of Satabus,

2 (p3) $w^{c} b$ nty (ir) hny $(. t)$

(the) priest who «is on duty,

3 (p) hlm-ntr Sbk-nb-Pay

4 p3 $n \underline{n} c^{c} 3$

(the) prophet of Soknopaios,

the great god

The purpose of these ostraca is not known. In DDD I we suggested that they served to select individuals for specific priestly positions. As such one could call them tickets or lots. A lottery is mentioned in the so-called agreements between the temple and priests, hwj qll "to throw the lot". ${ }^{2}$ Zauzich thought that these ostraca could have been used for elections, ${ }^{53}$ but in that case, one would expect the same person to appear multiple times, which is not the case, at least in the edited material. During the ostraca workshop, J. Lougovaya suggested another usage of this object type, namely as vouchers with which the individual could obtain a certain quantity of a product, food or similar (cf. the beer ostraca mentioned below). For the interpretation of the usage the original findspot could be crucial. As far as we know, the ostraca published in DDD I were found by Zucker mostly in a rubble heap outside the town wall, ${ }^{54}$ and more have been found by the recent Lecce missions on the spoil heap of Zucker's

51 Caputo 2019, 514-515.

52 DDD I, pp. 4, 102.

53 Zauzich 1997, 1060: "positiver Ostrakismus".

54 DDD I, pp. 1-2; Stadler 2012, 265-267 doubts the correctness of the entries in the excavation diaries by Schubart and Zucker and postulates a findspot between the temenos and the town wall. 
excavation in this area. ${ }^{55}$ However, Stadler notes that about 90 one-/two-name ostraca have been discovered in the last years in and around court C 1 of the Soknopaios temple, one of them in situ under the paving. ${ }^{56}$ Thus, it looks like these ostraca were first used, for whatever purpose, in the vicinity of the temple, and that most of them were later discarded outside the town. There are no indications for storage in an archive, as Stadler ${ }^{57}$ speculates.

At Hut-Repit, there are also a certain number of sherds that contain only a name with filiation. However, these fall into two categories: some seem in fact to belong to the same type as the one-name ostraca typical for Soknopaiou Nesos, but at Hut-Repit, there are comparatively few of them. In other cases, the names are written on large sherds and not even placed prominently in the middle: that makes it more likely that those sherds mentioning names with filiation derive from jar labels (see 2.5), indicating the vintner or the provider of the wine, or perhaps the owner of the amphora. The ceramological examination of these sherd is under way and will certainly help us to better understand this issue.

Besides lists with one and two columns and one-name/two-name ostraca, six other text forms can be identified, each attested only at one of the sites: beer ostraca, receipts, letters, school texts, texts with religious, magical and astronomical content and jar labels (dipinti).

\subsection{Beer Ostraca}

The beer ostraca, present only in Soknopaiou Nesos, show a date, one proper name with filiation and a quantity of beer. Given the so-called "Bierscheine" written in Greek from Tebtynis, these ostraca could have served as vouchers with which the individual could obtain the stated quantity of beer for a festival or another event in the temple milieu. ${ }^{58}$ However, a use as receipts for beer deliveries cannot be excluded either.

DDD I 198 (= TM 99510)

\section{Beer Ostracon}

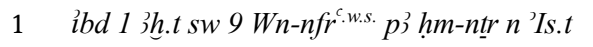

$2 \quad$ hnq.t $\check{s} \check{s} w 3 . t$

Month 1 of Akhet day 9: Onnophris ${ }^{\text {L.P.H. }}$, the prophet of Isis beer: 3 jugs

55 Stadler 2012, 266; Chiesi et al. 2012, 47, fig. 34.

56 Stadler 2012, 265-266 and fig. 1.

57 Stadler 2012, 266-267.

58 Reiter 2005, 133-136. 


\subsection{Jar Labels}

The jar labels (dipinti) from Hut-Repit are not in fact ostraca, because they were inscribed on complete vessels, not on sherds. Several hundreds of these have been found by now; the largest group comprises labels recording a year date without the name of a sovereign. The date is followed either by the words "the supplies from" or by an ordinal number and then a toponym, or simply by a toponym or a personal name. At least four different places have been identified so far, although only one of them can be located without doubt. Other labels seem to refer to the capacity and/or the content.

\subsection{Receipts}

Other text types unknown from the ostraca material from Soknopaiou Nesos are receipts for money or grain. Although present at Hut-Repit, these form a comparatively small group which has, however, slightly increased through the newest finds. Among them are some clear tax receipts, mainly for nhb.t tax. Others receipts for payments in money or grain seem connected to the temple administration, and sometimes the boundaries between "grouped receipts" (i. e. a series of receipts on the same ostracon or papyrus) and accounts of payments are difficult to draw. A very interesting type is represented by only four ostraca which seem to be receipts (or certificates?) concerning young red bulls, which probably were offered during funerary ceremonies for deceased persons with a special status. ${ }^{59}$

\subsection{Letters}

Among the small number of letters preserved on ostraca from Hut-Repit, some could be drafts for real letters or for legal documents written in letter form. Others might be letters to a god, and at least one is clearly a model letter used as a school exercise, as suggested by its extremely large handwriting.

59 Cf. PT 580 where the leg and other parts of a red bull are offered before the seven gates of the underworld, and BD 144, where Horus prepares the offering of a red bull, probably a symbol of Seth, to his father. See also P.Louvre E 7850 = TM 46143 (Cruz-Uribe 1985, 10-11, $\mathrm{n}^{\circ} 5$ [cited erroneously as Louvre E 7450]; Devauchelle 1987, 154-155; Donker van Heel, 1995, 222, $\mathrm{n}^{\circ} 22$ ), a letter by an overseer of the necropolis, acknowledging the receipt of a red bull for the funeral of a fourth prophet of Amon, although the current interpretation of this text seems to be that the bull in question was given as a payment in kind for the fee usually levied by the overseer of the necropolis ( $533 \mathrm{BCE}$, Thebes east). 


\subsection{School Texts}

That a school indeed existed at the temple of Hut-Repit is not only highly likely because an Egyptian temple is supposed to have a school, ${ }^{60}$ but is also confirmed by sherds with school exercises. Already present in the earlier finds, their number has increased significantly through the recent discoveries, probably because the school was one of the mud brick buildings within the temenos which the sebbakhin had dug up. Over 100 school ostraca recovered there attest to various stages of teaching and learning. There are sherds entirely covered with C-shapes, loops and zigzag lines, likely the product of the smallest children's efforts to master pen and ink; conjugations of verbs and phrases repeating the same verbal constructions over and over belong to the syllabus of more advanced pupils. There are Greek alphabets, rows of syllables (consonant-vowel and consonant-vowel-consonant combinations), and excerpts that look like Greek literary texts (although not yet identified) ${ }^{61}$; there are also sequences of Demotic and Greek cardinal numbers, arithmetic and perhaps geometric problems in Demotic and even a significant number of sherds with hieratic signs that seem too large to be anything else than a teacher's model or a pupil's copy.

\subsection{Texts of Religious, Magical and Astronomical Content}

The last, rather small group of ostraca from Hut-Repit contains Demotic (and some hieratic) texts that seem to have a religious or magical content. One seems to invoke Min in his role as a funerary deity, calling him "lord of the sacred land," that is, of the necropolis, and mentions a "chief of the akh spirits" and "the dead." Another example is perhaps magical rather than religious-above a pentagram, one line of Demotic looks at first glance quite unintelligible, but might have to be read backwards, word by word, which then would result in the phrase "It belongs to the god"; the sherd might have been used for a ritual of protection. Finally, there are also some astronomical ostraca with birth notes and horoscopes, that is lists of celestial configurations for a given date.

\section{Comparison}

A comparison of the ostraca material from Soknopaiou Nesos and Hut-Repit shows that, while accounts at Soknopaiou Nesos are quite homogenous in form, the same text type shows much more diversity in Hut-Repit. One possible explanation could

60 Quack 2002, 159-171.

61 On Greek literary ostraca in general, see Lougovaya in this volume. 
be that this is the consequence of different administrative proceedings. While the accounts in Soknopaiou Nesos seem to have been drawn up centrally by one single scribe at a time or, at the most, by a few well-trained individuals, those from Hut-Repit might have been produced by a larger group of people, who were not institutionally trained and thus could not (or did not have to) follow standard layouts.

We are of course aware of the fact that, in Soknopaiou Nesos as well as in Hut-Repit, the ostraca material we can analyze is entirely due to the chance of discovery, as neither of the two places has yet been excavated completely. Further finds could well change the impressions we have from looking at the sources available today. However, some text types from Soknopaiou Nesos seem indeed special: they have either never been found elsewhere, like the phyle counts, or never in such vast quantities, like the one- and two-name ostraca, which supports the idea that the temple administration of Soknopaiou Nesos had its own, very specific procedures.

Another difference is that women do not appear in the ostraca from Soknopaiou Nesos, while they are quite well represented in the material from Hut-Repit, especially as recipients of goods in various types of accounts. The reason for this phenomenon is still unclear.

\section{The Use of Ostraca as Writing Material and the Temple Book Keeping}

Finally, we should address the question, why these text types were written on ostraca and not on papyrus. All texts from Soknopaiou Nesos on ostraca come from the temple administration, and the majority of the sherds from Hut-Repit are also products of the local temple administration.

One of the characteristics of the ostraca from both sites is the scantiness of recorded information. This is of course only a problem for the modern researcher, since the original scribe and the recipient of the documents naturally had all the supplementary data necessary for understanding the texts, be it that they were common knowledge or that they were transmitted orally. One example is the allocation lists that are attested in Soknopaiou Nesos: in contrast to accounts, they do not give amounts, because all persons involved knew how much the listed people received, and therefore we assume that it was the same ration for everyone. Another example are accounts, which often give only numbers, but no units or measures, and sometimes do not even specify whether money or a product is meant, or whether it is received or given by the persons that are listed. Furthermore, these administrative documents on ostraca generally lack a complete dating-normally, we have either no date at all or just an indication of the day, rarely the month, while a regnal year is practically never mentioned, and when it is, the name of the king/emperor is lacking. This suggests that these sherds had only a limited 'useful life': accounts, allocation and attendance lists 
were preliminary notes for the temple book keeping and the information they contained was transferred onto papyrus within the next few days or at the most, at the end of the month, after which the ostraca could be thrown away, while the papyrus scrolls were archived. To use papyrus for such short-lived notes and drafts would have been a waste.

How straightened out Demotic accounts covering longer periods of time on papyrus look like is shown by the hundreds of fragments of book keeping records from Soknopaiou Nesos that sometimes are preserved at a length of several meters; a representative number of these texts will be published online in the research project DimeData (ANR/DFG) that has started in autumn 2018 in Bordeaux and Würzburg. To fulfill their obligations towards the state administration, the temples then drew up recapitulating accounts in Greek, like P.Louvre I 4 published by Jördens. ${ }^{62}$

In the same vein, drafts of letters could be written on ostraca because the texts were later recopied on papyrus. The astronomical ostraca concern the preliminary notes needed for casting a horoscope for the client, while the predictions themselves were probably given orally. Finally, pupils' exercises were per se ephemeral, while the texts the teacher prepared for use in class might have been written on ostraca for various reasons, for example because they were just excerpts from manuals on papyrus kept in the temple library.

62 Lippert 2010, 427-434. 


\section{Appendix}

Text Forms and Text Types attested on Demotic ostraca from Soknopaiou Nesos and Hut-Repit

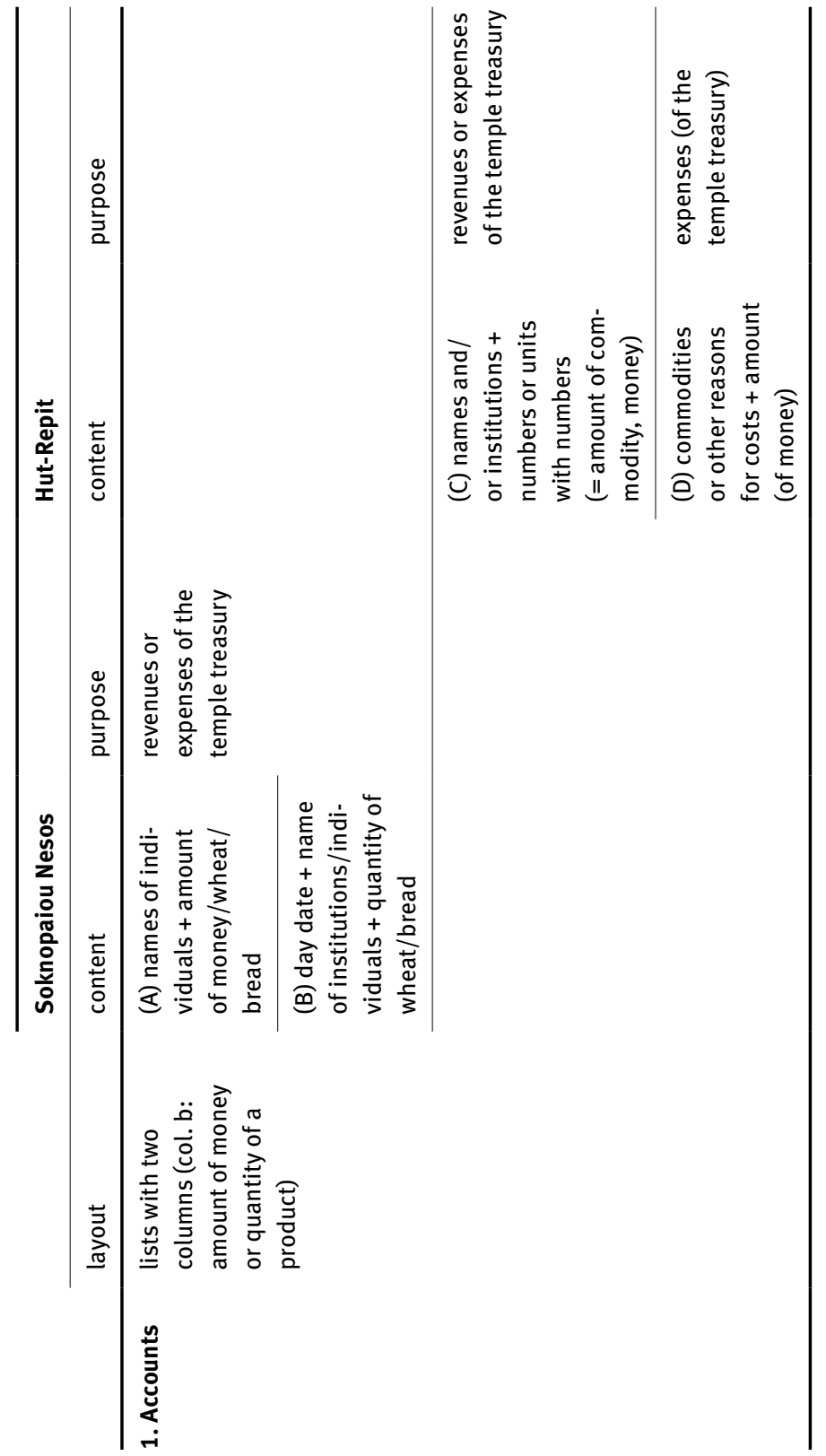



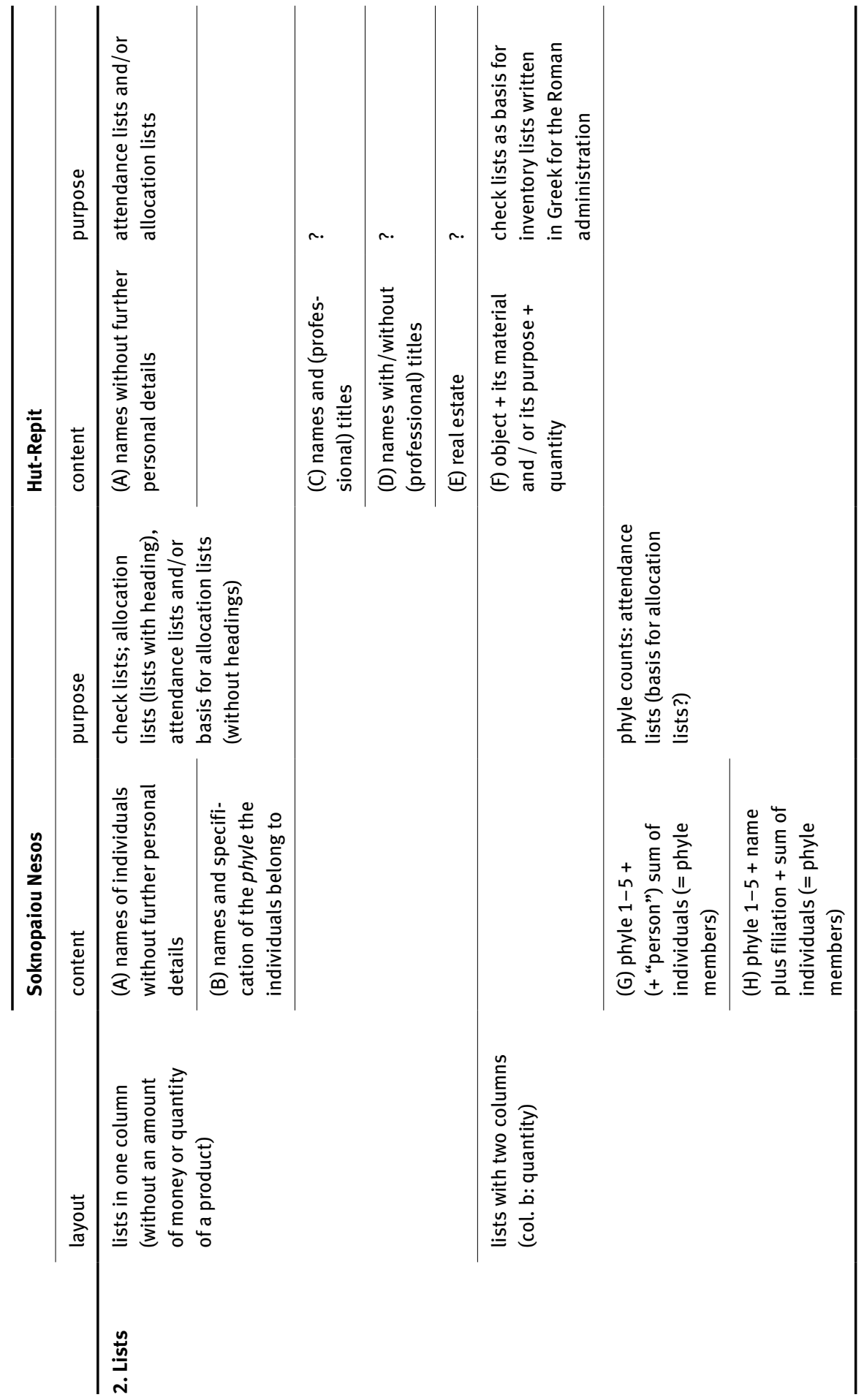


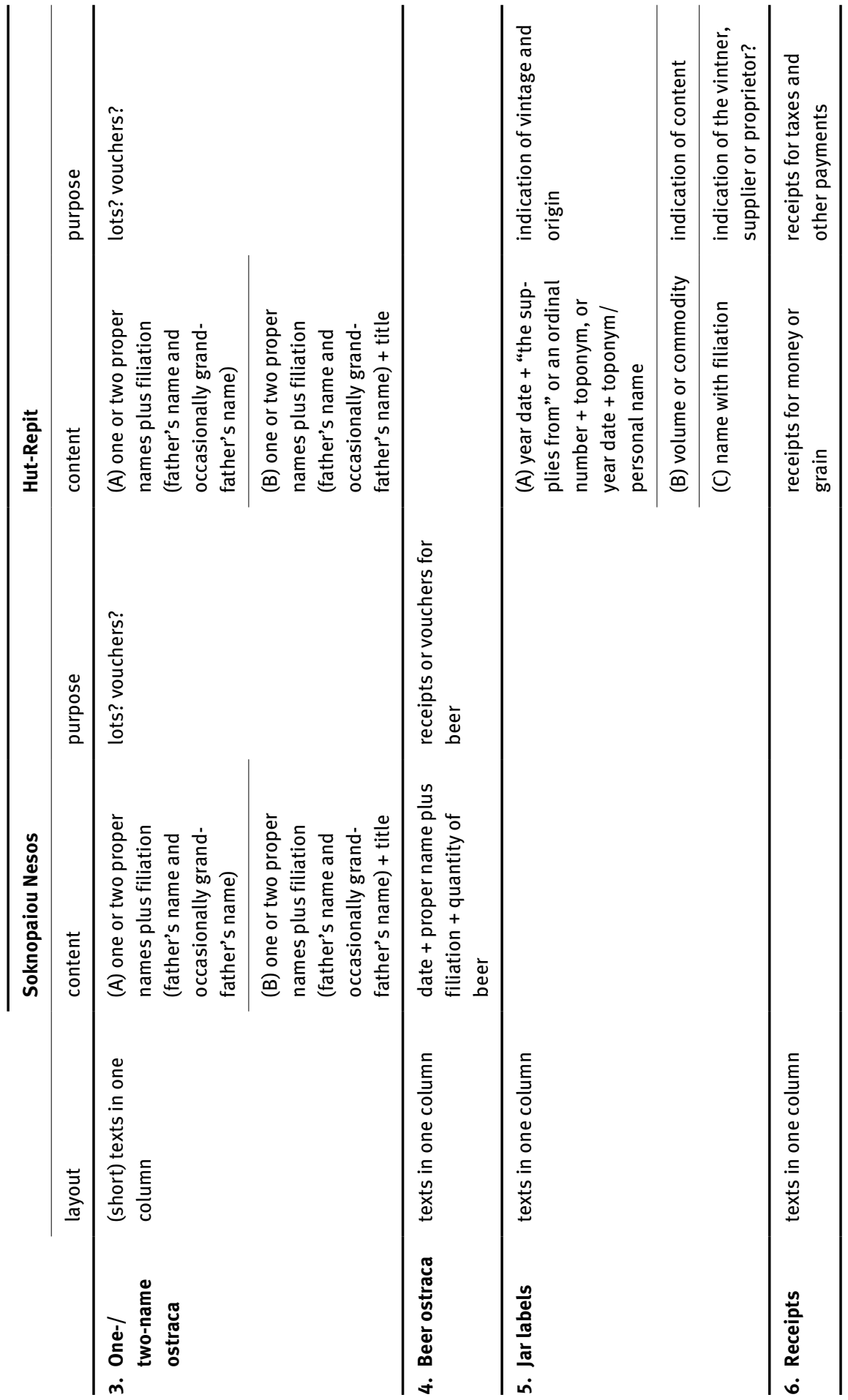




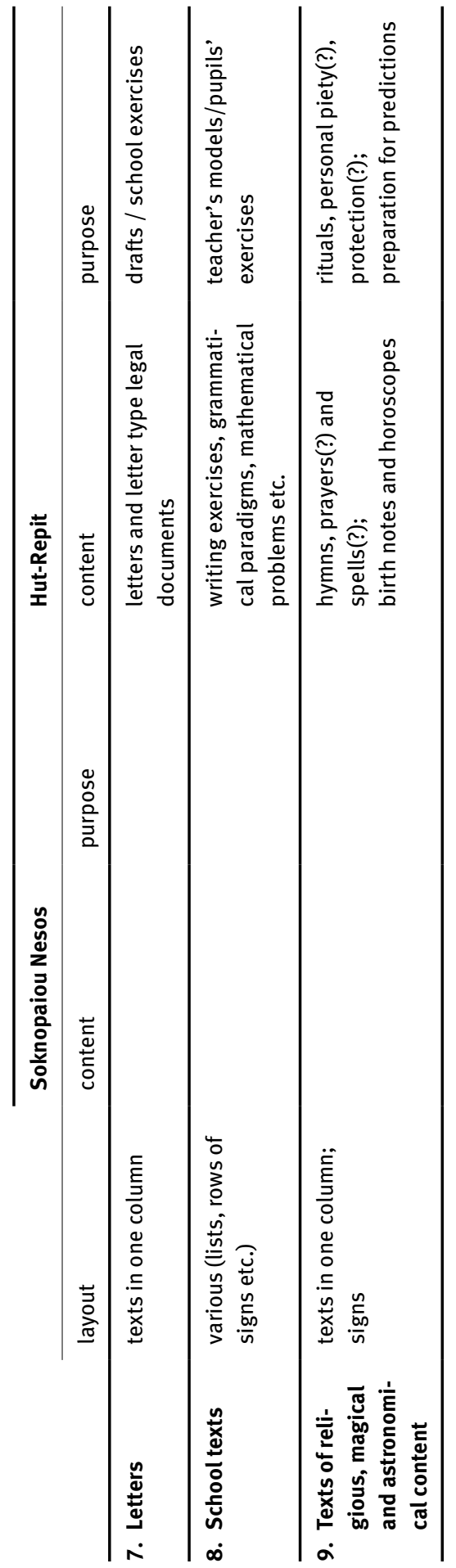




\section{Bibliography}

Abul-Yazid, Mohamed/Hammam, Sayed/Aberrahman, Sayed/El-Qadi, Alaa (2019), “Excavations in the Temple of Repit at Athribis in the 1980s", in: Marcus Müller/Mohamed El-Bialy/Mansour Boraik (eds.), Athribis V. Archäologie im Repit-Tempel zu Athribis 2012-2016 (Temples 15), Cairo, 427-436.

Boak, Arthur E. A. (1935), Soknopaiou Nesos: The University of Michigan Excavations at Dimê in 1931-32, Ann Arbor.

Capasso, Mario (2012), “I papiri e gli ostraka greci, figurati e copti (2001-2009)”, in: Mario Capasso and Paola Davoli (eds.), Soknopaiou Nesos Project I (2003-2009) (Biblioteca degli studi di Egittologia e di Papirologia 9), Pisa/Rome, 231-247.

Capasso, Mario/Davoli, Paola (2012), “Introduzione: Dime in età moderna”, in: Mario Capasso and Paola Davoli (eds.), Soknopaiou Nesos Project I (2003-2009) (Biblioteca degli studi di Egittologia e di Papirologia 9), Pisa/Rome, 11-18.

Caputo, Clementina (2019), “Dati preliminari derivanti dallo studio degli ostraca di Berlino (0. Dime) da Soknopaiou Nesos", in: Alberto Nodar and Sofia Torallas Tovar (eds.), Proceedings of the 28th International Congress of Papyrology (Barcelona 2016), Barcelona, 534-539.

Caputo, Clementina/Cowey, James M. S. (2018), "Ceramic Supports and Their Relation to Texts in Two Groups of Ostraca from the Fayum", in: Francisca A. J. Hoogendijk and Steffie M. T. van Gompel (eds.), The Materiality of Texts from Ancient Egypt. New Approaches to the Study of Textual Material from the Early Pharaonic to the Late Antique Period, Leiden/Boston, 62-75.

Chiesi, Ivan/Davoli, Paola/Occhi, Simone/Raimondi, Nicola (2012), “I rilievi topografici del sito”, in: Mario Capasso and Paola Davoli (eds.), Soknopaiou Nesos Project I (2003-2009) (Biblioteca degli studi di Egittologia e di Papirologia 9), Pisa/Rome, 23-81.

Clarysse, Willy (2005), “Tebtynis and Soknopaiu Nesos: The Papyrological Documentation through the Centuries”, in: Sandra Lippert and Maren Schentuleit (eds.), Tebtynis und Soknopaiu Nesos. Leben im römerzeitlichen Fajum. Akten des internationalen Symposions vom 11. bis 13. Dezember 2003 in Sommerhausen bei Würzburg, Wiesbaden, 19-27.

Cruz-Uribe, Eugene (1985), Saite and Persian Demotic Cattle Documents. A Study in Legal Forms and Principles in Ancient Egypt (American Studies in Papyrology 26), Chico.

Davoli, Paola (2015), “The Temple as a Spatial and Architectural Reality”, in: Mario Capasso and Paola Davoli (eds.), Soknopaios. The Temple and Worship. Proceedings of the First Round Table of the Centro di Studi Papirologici of Università del Salento (Lecce, October 9th 2013) (Edaphos 1), Lecce, 117-154.

Devauchelle, Didier (1987), “Notes sur l'administration funéraire égyptienne à l'époque gréco-romaine", Bulletin de l'Institut Français d'Archéologie Orientale du Caire 87, 141-160.

Donker van Heel, Koenraad (1995), Abnormal Hieratic and Early Demotic Texts collected by the Theban Choachytes in the Reigns of Amasis. Papyri from the Louvre Eisenlohr Lot. Dissertation thesis, Leiden University, Leiden.

Dousa, Thomas/Gaudard, François/Johnson, Janet (2004), “P. Berlin 6848, a Roman Period Temple Inventory", in: Friedhelm Hoffmann and Heinz Josef Thissen (eds.), Res Severa Verum Gaudium. Festschrift für Karl-Theodor Zauzich zum 65. Geburtstag am 8. Juni 2004 (Studia Demotica 6), Leuven/Paris/Dudley, MA, 139-222.

El-Farag, Rifaat/Kaplony-Heckel, Ursula/Kuhlmann, Klaus Peter (1985), "Recent Archaeological Explorations at Athribis (Hw.t Rpjj.t)", in: Mitteilungen des Deutschen Archäologischen Instituts, Abteilung Kairo 41, 1-8.

Jördens, Andrea (1998), Griechische Papyri aus Soknopaiu Nesos (P. Louvre I) (Papyrologische Texte und Abhandlungen 43), Bonn. 
Jördens, Andrea (2005), “Griechische Papyri in Soknopaiu Nesos”, in: Sandra Lippert and Maren Schentuleit (eds.), Tebtynis und Soknopaiu Nesos. Leben im römerzeitlichen Fajum. Akten des internationalen Symposions vom 11. bis 13. Dezember 2003 in Sommerhausen bei Würzburg, Wiesbaden, 41-56.

Lippert, Sandra (2010), "Seeing the Whole Picture - Why reading Greek Texts from Soknopaiou Nesos is not Enough", in: Traianos Gagos (ed.), Proceedings of the 25th International Congress of Papyrology, Ann Arbor, July 29-August 4, 2007 (ASP), Ann Arbor, 427-434.

Lippert, Sandra Luisa (2014), "Ostraca, Graffiti and Dipinti from Athribis in Upper Egypt - A Preview", in: Mark Depauw and Yanne Broux (eds.), Acts of the Tenth International Congress of Demotic Studies. Leuven, 26-30 August 2008 (Orientalia Lovaniensia Analecta 231), Leuven/ Paris/Walpole, MA, 145-153.

Lippert, Sandra Luisa/Schentuleit, Maren (2006), Ostraka (Demotische Dokumente aus Dime 1), Wiesbaden.

Lippert, Sandra Luisa/Schentuleit, Maren (2010), Urkunden (Demotische Dokumente aus Dime 3), Wiesbaden.

Pernigotti, Sergio (2008), “Ostraka demotici da Soknopaiou Nesos”, in: Ricerche di Egittologia e di Antichità Copte 10, 51-72.

Petrie, William Flinders (1908), Athribis (Publication of the Egyptian Research Account and the British School of Archaeology in Egypt 14), London.

Quack, Joachim Friedrich (2002), "Die Dienstanweisung des Oberlehrers im Buch vom Tempel”, in: Horst Beinlich, Jochen Hallof, Holger Hussy and Christiane von Pfeil (eds.), 5. Ägyptologische Tempeltagung, Würzburg, 23.-26. September 1999 (Ägypten und Altes Testament 33/3), Wiesbaden 2002, 159-171.

Reiter, Fabian (2005), "Symposia in Tebtynis - Zu den griechischen Ostraka aus den neuen Grabungen”, in: Sandra Lippert and Maren Schentuleit (eds.), Tebtynis und Soknopaiu Nesos. Leben im römerzeitlichen Fajum. Akten des internationalen Symposions vom 11. bis 13. Dezember 2003 in Sommerhausen bei Würzburg, Wiesbaden, 133-136.

Soknopaiou Nesos Project (SNP) Reports 2003-2017, http://www.museopapirologico.eu/sok_rep. htm (last accessed: 17.1.2020).

Stadler, Martin Andreas (2012), “Demotica aus Dime: Ein Überblick über die in Dime während der Kampagnen 2001-2009 gefundenen demotischen Texte", in: Mario Capasso and Paola Davoli (eds.), Soknopaiou Nesos Project I (2003-2009) (Biblioteca degli studi di Egittologia e di Papirologia 9), Pisa/Rom, 249-268.

Stadler, Martin Andreas (2015), "Archeology of Discourse: The Scribal Tradition in Roman Fayyum and the House of Life at Dime", in: Mario Capasso and Paola Davoli (eds.), Soknopaios. The Temple and Worship. Proceedings of the First Round Table of the Centro di Studi Papirologici of Università del Salento (Lecce, October 9th 2013) (Edaphos 1), Lecce, 189-232.

Tübinger Tempelprojekt Athribis, https://www.uni-tuebingen.de/fakultaeten/philosophischefakultaet/fachbereiche/altertums-und-kunstwissenschaften/ianes/forschung/aegyptologie/ projekte/athribis-projekt-dfg.html (last accessed: 17.1.2020).

Zauzich, Karl-Theodor (1997), “Demotische Ostraka aus Soknopaiu Nesos”, in: Bärbel Kramer et al. (eds.), Akten des 21. Internationalen Papyrologenkongresses Berlin, 13.-19.8.1995 (Archiv für Papyrusforschung und verwandte Gebiete, Beiheft), vol. II, 1056-1060.

Zauzich. Karl-Theodor (1984), “Die Bedingungen für das Scheiberamt von Soknopaiu Nesos”, in: Enchoria 12, 87-90. 


\section{Photo Credits}

Fig. 1: Courtesy of SNP-Soknopaiou Nesos Project.

Fig. 2: Modified by S. Lippert on the basis of a map supplied by the Tübinger Tempelprojekt Athribis. 